\title{
Penggunaan Media Box of Number and Alfabeth untuk Meningkatkan Kemampuan Kognitf, Bahasa dalam Mengenal Angka, dan Abjad
}

\author{
Khairunnisa Ulfadhilah ${ }^{1}$, Suyadi $^{2}$ \\ Pendidikan Islam Anak Usia Dini, UIN Sunan Kalijaga Yogyakarta, Indonesia ${ }^{(1,2)}$ \\ DOI: 10.31004/aulad.v4i1.93
}

$\triangle$ Corresponding author:

[19204030052@student.uin-suka.ac.id]

Article Info
Kata kunci:
Media Box of Number dan
Alfabeth;
Meningkatkan Kemampuan
Kognitif;
Bahasa anak;
Mengenal Angka dan Abjad

Keywords:

Media Box of Number and

Alfabeth;

Improving Cognitive

Ability;

Language;

Recognizing Numbers and Alphabets

\begin{abstract}
Abstrak
Media berfungsi penting untuk menggapai suatu pencapaian belajar sebab dapat memudahkan bagi pendidk disekolah untuk menjelaskan bahan ajar untuk pembelajaran, dan adanya media guna anak didik mampu menerima pembelajaran serta media memudahkan pendidik dalam memberikan stimulasi. Metode yang peneliti gunakan adalah kualitatif deskriprtif. Teknik pengumpulan data pada riset telah dilaksanakan merupakan observasi, wawancara, dan dokumentasi. Hasil penelitian dengan menerapkan langsung cara dalam pelaksanaan pengunaan media box of number, and alfabeth: 1) Guru meletakkan media of box number and alfabeth di depan, lalu menjejerkan kepingan-kepingan angka, dan huruf. 2) Guru mempersilahkan anak untuk mengambil kepingan-kepingan angka, dan huruf lalu memasukka sesuai tempat angka beserta huruf tersebut. 3) Setelah itu anak mengambil kepingan tersebut lalu menunjukkan ke guru beserta teman sebaya nya dikelas.
\end{abstract}

\begin{abstract}
The media has an important function to reach the learning report card because it can make it easier for school teachers to explain teaching materials for learning, and the media for receiving learning and the media make it easier for educators to provide stimulation. The method that researchers use is descriptive qualitative. The data techniques in research have been carried out by observation, interviews, and documentation. The results of the study by applying a direct method to the implementation of using numeric and alphabetical media: 1) The teacher places the media with square and alphabetic numbers in front, then lays up the pieces of numbers and letters. 2) The teacher allows the child to take the pieces of numbers and letters and then enter them according to the place of the number along with the letter. 3) After that the child takes the pieces and then shows them to the teacher and their peers in class.
\end{abstract}




\section{PENDAHULUAN}

Pembelajaran merupakan hal yang bernilai untuk manusia sebab dapat merubah kepribadian ataupun perilakunya, maka dari peran orang tua dapat mempengaruhi kepribadian seorang anak (Astuti \& Aziz, 2019). Orang tua dianjurkan memberikan rangsangan terhadap kepribadian anak dengan cara memberikan contoh pada anak, pembiasaan sehari-hari ketika di rumah bersama anak (Aisyah, 2017).

Anak usia dini menyukai konsep belajar sambil bermain, selain itu metode yang tepat diterapkan di sekolah PAUD dan sederajat merupakan bagian dari program untuk merubah tingkah laku untuk anak umur 0 hingga 6 tahun agar dapat mempunyai persiapan dalam hal pembelajaran berikutnya (Debeturu \& Wijayaningsih, 2019). Memfokuskan agar pembelajaran PAUD terhadap anak didik disekolah berjalan sesua pencapaian indikator, 6 aspek perkembangan anak dapat berjalan sesuai harapan, dan menstimulasi 6 aspek perkembangan melalui pembelajaran disekolah oleh pendidik, dan peran orang tua dapat menunjang stimulasi yang diberikan pada anak selama di rumah dikarenakan anak berada di lingkungan rumah lebih lama maka dari itu orang tua dapat menggunakan untuk memberikan stimulasi yang tepat untuk anak.

Menurut Hurlock, lima tahun awal umur anak- anak ialah tahap masa emas (golden age) tentang pertumbuhan anak, sebab anak akan menjajaki tahapan secara signifikan yang luar biasa (Ra \& Bima, 2021). Hurlock pula menjelaskan mengenai rentang umur yaitu masa krusial untuk pertumbuhan anak berikutnya (Hasmalena \& Rantina, 2017). Sejalan dengan itu pula, Berk menerangkan bahwa masa usia dini ialah masa dimana anak mengalami perkembangan serta pertumbuhan yang pesat yakni 6 aspek perkembangan yang sedang dihadapi anak yang berusia dini dalam tahap masa keemasan yan hanya datang sekali seumur hidup (Baharuddin, 2013). Perkembangan bagi anak usia dini penting distimulasi dan dirangsang oleh orang tua, memberikan stimulasi pada anak secara bertahap agar stimulasi secara optimal (Prahesti et al., 2019).

Aspek pertumbuhan maupun perkembangan memiliki indikator, pencapaian pertumbuhan maupun perkembangan anak secara signifikan yang perlu distimulasi oleh orang tua maupun pendidik selama anak berada di lingkungan sekolah. Indikator sebagai pedoman bagi guru maupun orang tua bahwasanya perlu untuk menstimulasi pertumbuhan, dan perkembangan anak. Memberikan asupan nutrisi yang sehat akan berdampak besar pada pertumbuhan maupun perkembangan anak, orang tua dapat memberikan asupan nutrisi yang bergizi, dan memantau asupan makanan anak selama di sekolah maupun ketika anak jajan di luar.

Pencapaian pertumbuhan anak perlu di dapatkan secara maksimal, diperlukan keterlibatan maupun keikutsertaan orang tuorang tua, serta meyediakan kemudia menyiapkan semaksimal mungkin di PAUD untuk dianjurkan untuk yang berbobot dalam pembelajaran (Sari \& Nofriyanti, 2019). Pada sesi pertumbuhan kognitif, anak usia dini 0- 6 tahun sedang mengalami momen sensoria dalam mengambil peran sebagai pendidik anak ketika dirumah (Warna et al., 2018). Pertumbuhan kognitif menjadi tumpuan awal bagi anak untuk memperluas keahlian pada usia dini. Dengan demikian keahlian anak disebabkan kepiawaian dalam menstimulasi agar mempunyai kaitan yang erat, dan memperluas keahlian maupun kemampuan yang lain. Kemampuan kognitif ialah keahlian menyelesaikan masalah sederhana seperti cara membereskan mainan ataupun berfikir, kecerdasan ialah keahlian untuk menekuni kemampuan serta menstimulasi anak perlu berinovasi, keahlian dalam hal nya menguasai apa yang terjadi di lingkungannya, dan kemampuan mengingat kejadian maupun hal-hal disekitar anak, serta menuntaskan penugasan dari pendidik namun yang menyederhanakan bagi anak usia dini.

Lingkup mengenalkan bahasa ialah merupakan pertumbuhan anak yang berarti dan wajib dicermati semenjak dini, dan perlu dirangsang secara bertahap sesai usia anak, dibantu oleh bahasa ibu serta komunikasi yang baik dalam keluarga (Ra \& Bima, 2021). Bagi Eli Tohanan bahwasanya bahasa adalah perlengkapan bernilai untuk setiap orang sebab menggunakan berbahasa maka anak akan bisa meningkatkan keahlian bersosialisasi dengan masyarakat (Pane, 2012). Mengangkat dari pendapat Nativisme, Chomsky memaparkan jika bahasa telah berada ketika anak sudah lahir. Ketika anak dilahirkan ke bumi kemampuan bahasa anak sudah diucap ketika menangis, menangis salah satu bahasa yang dikeluarkan dari mulut terlebih jika ketika anak dalam kandungan ibu, oang tua menstimulasi anak dengan cara mengaji, membacakan asma-asma Allah dekat berada ibu yang sedang hamil.

Perkembangan bahasa ialah sekian banyaknya bermacam perkembangan anak perlu dirangsang, dan distmulasi kemamapuan berbahasa agar komunikasi anak dengan yang lain lancar, dan jelas dalam berkosa kata. Dalam perkembangan bahasa anak usia dini pengucapan kosa kata yang masih terbata, dan belum jelas namun dapat diminalisir yakni dengan cara orang tua dapat memberikan stimulasi yang tepat untuk anak seperti mengajak anak berkomunikasi, mengenalkan anak perkosa kata, memberikan tontonan agar dapat melatih perkembangan bahasa, audi visual, dan mengajak anak untuk mendengarkan dongen yang dibacakan oleh orang tua. Ketika orang tua dapat memberikan stimulasi yang tepat, dan terjadwal maka perkembangan kosa kata anak bertambah, dan anak mampu berbicara dengan jelas. Perkembangan bahasa ialah suatu keahlian atau bakat dasar yang akan didigunakan oleh manusia. Setiap tahun nya anak akan bertambah kosa kata, pembendaharaan kata, dan anak akan mampu berkomunikasi dengan baik serta lancar walaupun akan ada beberapa kosa kata yang kurang jelas dikarenakan terdapat beberapa anak yang masih mengalami cadel pada lidah, sulit mengelurkan beberapa huruf seperti "R, dan L". Berkomunikasi anak usia dini pada umumnya sudah terlihat kemajuan dan signifikan untuk penambahan kosa kata dalam pengucapan sehari-hari. Kemampuan bahasa diibartkan sebagai alat berkomunikasi dengan lingkungan disekitarnya yang akan 
berpengaruh untuk masa depan anak. Dalam mengenalkan bahasa anak usia dini orang tua mempunya peran yang sangat besar dan berpengaruh, dengan adanya bahasa dapat mengemukakan apa yang anak rasakan, ataupun yang anak inginkan ataupun yang anak butuhkan selama ini.

Kemapuan perkembangan kognitif, bahasa anak usia dini perlu distimulasi oleh orang tua ketika anak berada dirumah, dan guru pun perlu menstimulasi anak ketika disekolah. Dengan berbagai macam alat permainan edukatif atau menggunakan media seperti box of number, and alfabeth guna untuk meningkatkan kemampuan anak dalam aspek pekembangan kognitif, dan bahasa anak usia dini. Menggunakan barang-barang yang terpakai yang dibuat sekreatif mungkin oleh peneliti agar dapat menstimulasi perkembangan kognitf, dan bahasa anak. Penelitian ini ditujukan agar mengetahui anak dalam mengembangkan kemampuan kognifi, dan bahasa anak lewat penggunaan media box of number, and alfabeth sebagai salah satu alternatif bagi para pendidik untuk memberikan bahan ajar bagi anak-anak di RA Miftahul Huda. Pendidik menggunakan bahan ajar untuk anak usia dini mengunakan media ini untuk meningkatkan kosa kata anak jelas, yakin diri anak untuk berbicara dengan metode yang mengasyikkan, keahlian menyelesaikan persoalan dalam kehidupan masing-masing anak.Aanak ketika dirumah ataupun disekolah menggunakan metode mudah yang sederhana untuk anak, dapat berbaur dengan teman sebaya nya maupun lingkungan sekitar, dan mengaplikasikan pengetahuan ataupun kegiatan dalam konteks yang baru, dan berpikir secara logika pada anak sedini mungkin

Anak yang berusia 0-6 tahun dinamakan usia dini, dan mempunyai kepribadian unik, memiliki tahapan perkembangan dan pertumbuhan dalam diri anak berumur 0-6 tahun terdapat aspek fisik, kognitif, sosial emosional, kreativitas, bahasa dan komunikasi digunakan yang tepat dengan proses yang sedang dipijaki oleh anak usia dini. Terdapat sebagian definisi mengutarakan pendapatnya, peneliti merumuskan bahwasanya anak yang berusia 0-6 tahun merupakan anak yang berumur 0- 6 tahun dalam tahap perkembangan serta pertumbuhan sesuai pencapaian indikator (Anggraini, 2019).

Ketika anak usia dini kerap diucap sebutan" golden age" ataupun masa keemasan. Dalam hal ini nyaris segala kemampuan anak mengenai kepekaan anak timbul untuk berkembang serta tumbuh secara signifkan dan hebat. Pertumbuhan tiap anak tidak sama sebab tiap anak mempunyai pertumbuhan yang berbeda, santapan dan konsumsi anak berbeda, dan rangsangan dari orang tua yang inensif sangat diperlukan untuk perkembangan dan pertumbuhan anak agar mempnyai kemajuan. Sebagaimana mestinya anak perlu diberikan stimulasi maupun rangsagan secara intensif, dan berkala dari orang tua ketika dirumah, pendidi ketika disekolah, dan lingkungan yang mendukung akan proses aspek perkembangan anak (Wasik, 2012). Saat anak- anak memasuki tahapan kemudian meningkatkan kemampuan yang terdapat dalam dirinya, mereka akan berekspesi menyenangkan ketika melakukan kegiatan yang ia sukai seperti halnya bermain dirumah maupun diluar bersama teman sebayanya, selain bermain meningkatkan kognitif, bahasa anak pun terlatih dengan adanya berinteraksi, dan berkmuniksi dengan teman sebaya. Sedemikian diperlukan usaha dalam hal pembelajaran untuk menggapai menyeluruh secara optimal dalam perkembangan anak usia dini mengenai pertumbuhan fisik ataupun pertumbuhan psikis. Kemampuan anak sangat berarti, dan penting untuk dikembangkan, menstimulasi secara tepat sesuai usia anak. Potensi- potensi tersebut seperti halnya nilai agama, dan moral, fisik motorik, kognitif, bahasa, sosial emosional, dan seni.

Pertumbuhan masa kanak-kanak merupakan pndasi dasar pada masa keemasan anak yakni anak usia dini akan cepat menangkap stimulasi yang diberikan oleh pendidik ketika dikelas (Mardliyah et al., 2021). Anak hendak menangkap bahan ajar dari pendidik di sekolah, pendidikan di lingkungannya untuk mengemumangkan keahlian, dan kemampuan dirinya sebab anak usia dini akan timbul keingintahuan tingi (Made et al., 2018). Anak usia dini adalah bentuk ekspresi anak yang sedang menghadapi fase yang sangat kilat dalam rentang perkembangannya, sebab anak usia dini merupakan peniru yang ulung apa yang mereka amati tentu mereka tiru untuk itu dalam mempersiapkan untuk kehidupan berikutnya, dalam proses pendidikan yang dapat menstimulus pertumbuhan anak (Islam et al., 2021).

Anak yang berusia 0-6 tahun ialah momen tumbuh kembang anak dapat pula memastikan pertumbuhan fase berikutnya maka dariitu orang tua mempunyai peran yang sangat besar untuk menstimulasi semua aspek perkembangan anak agar tercapainya semua pencapaian indikator (Satrianingrum \& Prasetyo, 2020). Bedasarkan riset yang dicoba para pakar merumuskan jika pembelajaran anak disekolah dapat diperbaiki dalam halnya prestasi, akademik, dan akan menjadi tolak ukur ketika anak kerja di masa dewasanya kelak nanti dan mempersiapkan masa depan. PAUD ialah salah satu jenjang pendidikan untuk anak berusia 4-6 tahun, mempunyai peran strategis, dan membantu peranorang tua untuk mendidik, menstimulasi semua aspek perkembangan anak ketika berusia dini. Dalam proses pembelajaran secara tertata sebab merupakan landasan, dan mempersiapkan untuk anak- anak cerdas. Usia dini ialah fase anak mengembangkan segala yang ia miliki, akan sangat menentukan untuk anak di masa depannnya namun dilihat ari cara orang tua dan pendidik merangsang kemapuan ank dalam berbagai aspek perkembangan (Suyadi, 2015).

Anak berusia 0-6 tahun ialah periode dini yang berarti, dan sejauh dalam perkembangan dan pertumbuhan anak. Ketika anak berusia dini seluruh kemampuan tumbuh sangat cepat, dan kilat. Seorang pakar neuorologi, memaparkan jika sekitar 50\% kemampuan bernalar sanggup terjalin pada berusia 4 tahun serta $80 \%$ sudah terjadi kala berumur 8 tahun. Fase kanak-kanak akan menjajaki masa keemasan (the golden) yang dimana pada masa ini anak merasakan ataupun mengetahui bermacam dorongan maupun stimulasi yang diberikan oleh orang tua, dan 
pendidik. Fase peka merupakan momen terbentuknya area fungsi tubuh, serta mental yang siap merespons stimulasi yang diberikan oleh lingkungan. Fase kini pula ialah pondasi dasar untuk meningkatkan kemampuan kognitif, fisik motorik, bahasa, sosio- emosional, agama, dan moral, dan seni. Menggiatkan untuk anak lewat sekolah RA dan sederajatnya dapat menghasilkan sel-sel saraf anak maksimal, agar bermanfaat untuk pertumbuhan kecerdasan otak anak. Sel-sel saraf otak akan mengotomatiskan kemudian mengacu pada pertumbuhan semacam nilai agama dan moral, kognitif, sosio- emosinal, kreativitas, bahasa dan seni (Yaswinda et al., 2020). Kemampuan maupun peran seni dalam diri anak usia dini tidak dapat dilupanja begitu saja, sebab seni sudah menjadi bagian dari kehidupan anakanak tidak hanya itu dunia anak- anak bermain. Dengan bermain dapat dicampurkan dengan seni agar anak lebih memahami tentang seni (Mulyani, 2017).

Manfaat dari PAUD meningkatkan karakter, dan kemampuan secara optimal, membagikan stimulasi ataupun rangsangan dan berpotensi agar anak dapat meningkatkan masa the golden age. Di selengarakan PAUD bertujuan untuk kesiapan anak memasuki pendidikan lebih lanjut, menolong sejak awal agar kelalaian tidak terjadi disebabkan awam akan penting pendidikan, tingkatkan kualitas pembelajaran, kurangi laju putus sekolah (Suyadi, 2015). Hendak memahami dan menguasai akan perkembangan anak dari bermacam aspek nilai agama dan moral, fisik motorik, kognitif, sosial emosional, bahasa dan seni. Akan mengenali pembelajaran sosial yang tepat yang hendak diterapkan dalam kehidupan anak- anak, dan memperoleh panduan Islam dalam menanamkan pembelajaran kepada anak dengan metode yang sangat efisien, aplikatif, pas dan target dengan sederhana (Aip Saripudin, 2017).

Kemampuan kognitif anak usia dini ialah pembelajaran formal yang bertujuan menunjang anak didik disekolah meningkatkan bermacam kemampuan tubuh serta mental terdapat nilai- nilai agama dan moral, fisik motorik sosial, emosional, kemandirian, kognitif, bahasa, dan seni. Agar menyiapkan untuk jenjang selanjutnya (Anggraini, 2019). Dijelaskan bahwa pembelajaran dibutuhkan untuk kehidupan manusia terlebih untu anak usia dini yang sedang mengalami masa keemesaan (golden age) yang hanya datan sekal seumr hidup. Perkembangan kognitif ialah hal yang merujuk kepada cara anak berpikir memakai logika, dan ketika nak sedang mengalami dan mengasah dala hal kognitif orang tua perlu mendampingi agar anak terarah dalam aspek perkembangan kognitif yang dimulai sejak usia 1 tahun sudah ada pertanyaan dari anak dan aka berlanjut pada usia anak selanjutnya. Pemamaparan dari Gardner yang menerangkan jika pemikiran anak usia dini dalam aspek kognitif sebagai kemampuan bagi anak usia dini untuk memecahkan permasalahan, dan mengenai ekspolarasi anak (Made et al., 2018).

Menurut Dian Anggraini dan Suyadi mengatakan bahwasanya pencapaian anak didik akan selalu dalam pengawasan pendidik ketika dilingkungan sekolah maupun ketika anak berada dirumah, maka hal tersebut pendidik dan orang tua bekerja sama untuk memantau kemampuan kognitif anak sebab penting untuk memantau perkembangan anak agar dapat teralisasi dalam indikator pencapaian anak. Selain itu, pendidik melakukan penilaian capaian anak didik dilakukan setiap anak berangkat sekolah, melakukan aktifitas maupun kegiatan selama dilingkungan sekolah.

Menurut Kartadinata mengatakan jika pertumbuhan otak, struktural otak anak berkembang terus setelah lahir (Khadijah, 2017). Beberapa studi memaparkan jika anak usia dini akan melewati tahap imajinasi yang terjalin jika ayah ibu dan pendidk menstimulasi dengan baik, komunikasi sekaligus interaksi terjalin erat antara ibu ayah maupun putra putrinya, ayah ibu akan mengajak anak untuk mendengarkan mebaca buku cerita, donggeng karena perlu anak distiumulasi dengan cara metode berceritaakan meingkatkan kemampuan imanjinasi maupun kosa kata anak dalam berbahasa. Secara otomatis akan membentuk jaringan otak anak. Penjelasan diatas menunjukan bahwa penting nya peran orang tua dalam hal merangsang kemampua kognitf maupun bahasa anak dengan berbagai macam cara stimulasi, dan kedekatan orang tua dengan anak sangatlah penting, ana akan merasakan kehanatan dalam diri orang tua, dan ikatan batin anak dan orang tua akan lebih kuat. Adanya perkembangan kognitif berguna bagi anak untuk mengeksplor dalamhal berpikir dengan logik adanya teori kognitif orang tua, dan pendidk mepunya pedoman ketika mendidik anak serta mengarahkan kemampuan anak ke tiap-tiap bidang aspek perkembangan. Perkembangan kognitif mempunyai macam-macam aspek dalam bidang kognitif seperti ingatan anak yang kuat, mampu merangsang kemampua otak, rasa ingin tahu anak berasal dari pemikiran anak yang kritis dan dapat memecahkan masalah seperti mengelompokkan suatu benda contohnya media box of number, and alfabeth yang dirancang oleh periset agar dipraktekan kepada anak usia dini disekolah RA Miftahul Huda Cirebon.

Hurlock menyatakan jika 5 tahun awal dalam kehidupan anak ialah pondasi dasar yang kuat untuk pertumbuhan maupun perkembangan anak berikutnya. Rasa senang yang diciptakan oleh orang tua, orang-orang sekitar anak, lingkungan sekolah maupun pendidik disekolah akan berdampak sagat baik untuk semua aspek perkembangan anak usia dini karena disekitar anak memberikan cinta, rasa damai, rasa nyaman dapat berpengaruh positif bagi anak usia dini secara fisik maupun mental anak. Dalam hal pembelajaran di RA anak distimulasi dengan cara bercerita, bernyanyi, mengenalkan angka, huruf, menyatukan kosa kata, mampu membedakan benda-benda, bernyanyi mengenalkan berbagai macam, dan lain sebagainya. Kognitif bagi anak usia dini sangat penting sebab berbungan dengan logika agar anak dapat mengelompokkan untuk masalah seperti bermain puzzle, kolase, dan anak diajarkan sedini mungkin cara menyelesaikan masalah (problem solving).

(Suyadi, 2015) menjelaskan jika pembelajran kognitif untuk anak usia dini sebaiknya dicoba secara bertahap dengan melihat kemajuan anak dalam aspek kognitif, mulai dari yang sederhana hingga mencapai harapan pendidik, 
ibu ayah. Anak mempunyai ketertarikan terhadap sesuatu yang baru dapat memicu rasa ingi tahu anak yang tinggi, mempunyai rasa ingin mencoba, selalu ingin tahu, dan pada saat ia sanggup melaksanakan kemudian melakukan hal yang sama sebab bagi anak hal yang menyenangkan baginya.

Suyadi menjelaskan bahwa anak berusia dini telah dapat mengucapkan bahasa secara bertahap, dan signifikan kemajuan jika orang tua menstimulasi dengan cara melakukan berkomunikasi dengan anak maka anak pun akan merekam lalu menirukan kosa kata, selain itu dapat dilakukan dengan metode bercerita maupun mendonggeng pada ank usia dini untuk menambah kosa kata, pembendaharaan kata demi kata, orang tua perlu mengajarkan katakata mudah seperti ibu, ayah, kakak ataupun kosa kata yang mudah untuk anak ucapkan, dapat juga menggunakan video yang berisikan pelafan kosa kata dengan cara yang mengasyikan selai itu dapat menggunakan melalui gambar untuk mengenalkan sekaligus dapat menyebutkan. Kosa kata anak usia dini sudah mampu menyebutkan,dan mengingat 14.000 kata lalu anak dapat mengucapkan beberapa kosa kata, dan kecepatan bahasa anak usia dini masih lamban seiring usia akan akan semakin meningkat.

Papalia menarangkan jika keahlian berkomunikasi anak berumur 4 hingga 6 tahun telah sanggup memahami maupun mengerti kata simpel dan memahami sebagian sinonim walaupun pengucapan kosa kata kurang jelas dikarenakan lidah anak usia dini. Anak telah sanggup menggunakan beberapa kosa kata, dan pengucapan sekaligus. Selain itu, anak sudah mampu membedakan arti kosa kata, dan dapat mengartikan kata-kata yang mudah diterima untuk anak usia dini. Peran ayah ibu memiliki andil penting dalam perkembangan bahasa, ayah ibu mencontohkan bahasa dengan baik, mengenalkan kosa kata maka dari hal tersebut anak akan menirukan lalu merekam di ingatan mereka ketika melihat maupun mendengar (Amini, 2020).

Perkembangan bahasa ialah keahlian yang berarti bagi anak, bahasa anak merupakan yang ia utarakan, pengucapan dalam kosa kata yang digunakan anak dalam sehari-hari nya. Menetap nya anak akan berpenagruh dalam perkembanga bahasa, dan bahasa yang digunakan jika anak menetap di suatu daerah yang menggunakan bahasa daerah maka anak pun akan mengikuti bahasa daerah tersebut contohnya ketika anak menetap di cirebon maka anak akan mengucapkan bahasa jawa, dan sunda sebab cirebon mempunyai 2 bahasa daerah yaitu jawa, serta sunda. Jika anak menggunakan bahasa daerah, orang tua pun harus mengajarkan bahasa indonesia dengan baik, dan benar.

Menurut Nur Amini dan Suyadi menjelaskan jika kosa kata anak perlu adanya diasah pengucapan agar lidah nya tidak kaki jika distimulasi dengan tepat anak mampu berbaur dengan lingkungannya. Selain itu, melalui kosa kata anak akan dapat menyampaikan apa yang ingin diutarakan, bercerita kepada orang tua mengenai ketika berada disekolah sebab penting sekali ketika anak berusia dini untuk bercerita, melatih kemampuan berbahasa serta menjalin kedekatan anak dengan orang tua tentunya.

Dalam Peraturan Pemerintah Pendidikan serta kebudayaan Nomor 137 Tahun 2014 mengenai bahasa anak, meliputi: a) Mengerti apa yang orang lain ucapkan, menguasai dongeng, peraturan, mengenal kosa kata melalui buku ceirta, dongeng, maupun buku yang ada ketika disekolah. b) Berekspresi bahasa jika pengucapan kosa kata anak bahagia ia pun akan bereskpresi senang, bahagia, anak akan mengajukan pertanyaan jika menurut nya tak mengerti, anak dapat menanggapi lawan bicara dengan porsi usia anak, berkomunikasi dengan baik. c) Pemahaman anak mampu menyeterakan bentuk, benda disekitarnya, menyebutkan kosa kata atau mengulang pengucapan orang tua, dan mampu memahami donggeng maupun anak mampu bercerita kepada orang tua.

Bahasa merupakan mengantarkan suatu yang terlintas di dalam hati, dan pikiran. Tetapi, bahasa pula dapat digunakan untuk berinteraksi dengan yang lain. Dalam riset bahasa diartikan sebagai komunikasi, pengucapan kosa kata, gerakan jari tangan untuk mengisyaratkan bahasa kepada orang tuna wicara. Pengucapan bahasa anak usia dini melalui yang dilihat maupun mendengar dari sekitar, jika lingkungan sekitar memberikan bahasa sopan santun secara tidak langsung anak dapat menirukan sopan santun pula. Perkembangan bahasa anak diartikan sebagai pijakan anak ketika untuk mengucapkan kosa kata, mengutarakan apa yang ingin dikatakan, mengenalkan berbagai macam dilingkungan sekitar, menyebutkan kemudian bertanya apa yang ingin anak ketahui. Perjalanan aspek bahasa anak usia dini hingga anak mampu menyebutkan kosa kata melalui stimulasi dari orang tua ketika berada dirumah, dan pendidik disekolah berupaya untuk menstimulasi, merangsang kemampuan bahasa anak usia dini dengan cara bernyanyi, bercerita, dan tanya jawab.

Menurut Enung Fatimah, bahwasanya bahasa dikuasai oleh anak adalah bahasa yang berkembang di dalam keluarga sebab peran keluarga akan berpangaruh besar dalam mengoptimalkan bahasa anak usia dini, yang mendapatkan julukan "bahasa ibu". Angka akan meningkat jika dalam tahap memperkenalkan bahasa menggunakan bahasa ibu di padupandankan serta diperluas dengan adanya bahasa Indonesia yang menyatukan beserta bahasa tradisonal sebab ketika menetap disuatu daerah akan berpangaruh pula dengan bahasa daerah yang tentunya akan menjadi bahasa sehari-hari selain bahasa Indonesia. Hal ini berpengaruh pada nada bicara, logat yang dihasilkan dari berinteraksi di lingukungan sekitar maka menjukkan identitas anak dikarenakan akan berpengaruh pada bahasa suatu wilayah atau yang biasa disebut dengan bahasa tradisional (Anggraini, 2019). Dapat disimpulkan dari pendapat tokoh atas penjelas sebelumnya, jika anak usia dini memiliki penambahasan kosa kata, pengucapan bahasa dari pencampuran bahasa ibu dan ruang lingkup tempat tinggal yang memakai bahasa daerah tertentu, dengan seiring bertambah usia anak maka akan tambah pengucapan. 
Jamaris menjelaskan pada hakikatnya kemampuan bahasa anak usia 5-6 tahun yakni: 1) Anak dapat pengucapan lebih dari 2.500 kosakata, 2) Anak mampu menirukan, dan mendengarkan ucapan yang baik, 3) Anak mampu mengikuti dalam suatu obrolan, 4) Anak mampu mendengarkan ucapan orang lain, berkomunikasi dan memberikan tanggapan atas komunikasi dengan orang lain. 5) Anak mampu menyebutkan kosakata mengenai seperti warna, tempuh, danaspek fisik motorik (Ilmiah et al., 2018).

Metode pembelajaran yang dilakukan dan diimplementasikan oleh pendidik yaitu metode bertanya kemudian anak menjawab pertanyaan dari pendidik, yang dilakukan pada kegiatan pembelajaran dikelas. Tanya jawab hanya ditanggapi oleh sebagian anak, adapula beberapa anak diam tidak memberika tanggapan apapun, terdapat anak yang menggapi pertanyaan dari pendidik menggunakan suara tak lantang disebabkan malu. Terdapat berbagai cara sebagai solusi untuk menganggulangi masalah dalam berkomunikasi pada anak usia dini. Sebagaimana tertuang di landasan dasar pembelajaran di Kurikulum 2013 terdapat langkah-langkah yang tepat untuk anak usia dini yakni, demonstrasi, bercakap-cakap, bercerita, serta bermain peran.

\section{METODE}

Penelitian ini dipakai dengan riset ini menggunakan metode kualitatif dengan menjabarkan riset ini. Riset ini memakai pendekatan kualitatif yakni Penggunaaan Media Box of Number, and Alfabeth untuk meningkatkan kemampuan kognitif, dan bahasa dalam mengenal angka, dan abajad di RA Miftahul Huda Cirebon.

Penelitian ini dilakukan di RA Miftahul Huda Cirebon dengan menggunakan metode mengumpulan informasi dalam riset ini adalah wawancara, dokumentasi, dan observasi. Peneliti melakukan observasi melihat kurikulum yang diterapkan di RA Miftahul Huda Cirebon, struktural sekolah, visi misi sekolah, sejarah berdirinya, dan terbentuknya sekolah. Subjek penelitian yakni pendidik kelas A1, A2, B1, B2, dan orang tua RA Miftahul Huda Cirebon. Selanjutnya wawancara merinci oleh peneliti dilakukan dengan bertanya langsung pada pendidik di RA Miftahul Huda Cirebon. Teknik pengumpulan data dilakukan dengan dokumentasi bagaimana anak mempraktekan media box of number, and alfabeth berupa foto-foto maupun video. Instrumen dilakukan mengumpulkan data dibantu oleh narasumber yakni pendidik di RA Miftahul Huda Cirebon yang membantu peneliti dalam melakukan mengumpulkan data dengan cara bertanya, mendengar, dan mengambil data yang dibutuhkan.



\section{Gambar 1. Desain Penelitian}

Riset ini memakai analisis data kualitatif agar dari hasil tersebut dideskripsikan, dan dijabarkan mengenai kata-kata tertulis ataupun melalaui perkataan. Adapun hasil riset yang dilakukan pada anak yaitu, anak mengenal angka, abjad melalui box yang dikonsep dengan angka maupun abjad yang sudah terkonsep sebelumnya, anak mampu menyebutkan angka, abjad maupun warna yang ada pada kepingan angka dan abjad, memasukan kepingan angka maupun abjad sesuai dengan box yang sudah tersedia selain itu melatih anak dalam kemampuan kognitif, dan kemampuan bahasa anak usia dini.

\section{HASIL DAN PEMBAHASAN}

Media diartikan sebagai macam-macam bahan ajar untuk proses belajar-mengajar pada anak yang mampu menstimulasi, dan mengajarkan pada anak (Hignasari, 2020). Arti dari media membantu pendidik dalam menerangkan pembelajaran ketika dikelas selain itu, media berfungsi sebagai agar anak tidak mersakan monton atau disebut bosan dengan adanya media anak akan lebih fokus, rasa ingin tahu yang tinggi terlebih jika media tersebut anak pertama kali melihat akan menumbuhkan antusias yang tinggi untuk anak usia dini (Baharun \& Saleha, 2021). Dari situlah peneliti membuat media box of number, and alfabeth dan ketika diterapkan pada anak-anak reaksi anak antusias sekali sebab pertama kali anak melihat media tersebut, selain itu terdapat bentuk box yang ukuran yang tepat untuk seusia dini. Bentuk box yang unik dari bahan yang tak terpakai berubah menjadi media yang bermanfaat, dan dapat menjadi metode stimulasi untuk merangsang kemampuan kognitif maupun kemampuan bahasa anak serta mampu mengenalkan angka, abjad selain itu di dalam box terdapat tulisan sesuai angka, abjad dan sesuai kepingan yang bertuliskan angka maupun abjad. Terdapat berbagai macam warna seperti merah, hijau, hitam, 
biru di kepingan angka, abjad dan kolom box tersebut. Kepingan angka, dan abjad dibuat ukuran sesuai untuk usia dini sebab menyesuaikan dengan tangan mungil, tulisan angka dan abjad didesain tidak terlalu besar ataupun tidak terlalu kecil namun ukuran yang sedang. Bahan maupun alat pembuatan media sederhana, memanfaatkan barangbarang bekas disekitar agar tidak menambah sampah, dan mendukung program pemerintah untuk mengurangi sampah, maka dari itu peneliti membuat serta mendesain semenarik mungkin sehingga agar bermanfaat, dan penunjang media pembelajaran anak ketika dirumah terlebih pada pandemi saat ini dikarekan virus covid-19.

Menurut Cut Citra Novita dan Suyadi memaparkan adanya virus Covid-19 sangat berdampak besar, dan berakibat pada proses pembelajaran ketika disekolah jika sebelum adanya pandemi ini anak-anak melakukan kegiatan proses belajar-mengajar secara tatap muka namun kini diahlikan sementara dengan via online menggunakan aplikasi whatsapp, zoom, google meeting ataupun website lembaga sekolah. Peran pendidik disekolah diambil alih oleh orang tua untuk mengawasi, membimbing putra putri nya melakukan pembelajaran via online (Novita, 2020).

Riset bertujuan untuk menggunakan suatu media yang berbentuk media box of number, and alfabeth guna dapat mengenalkan angka, dan abjad pada anak di RA Mifatahul Huda Cirebon. Berdasarkan hasil riset dengan melakukan observasi dan wawancara yang sudah periset jalani 12 November hingga 02 Desember 2020 di RA Mifatahul Huda Cirebon, dapat dilihat bahwa metode pendidik dalam menggunakan media box of number, and alfabeth dapat meningkatkan kemampuan kognitif, dan bahasa anak (mengenal huruf, dan abjad). Tetapi di pandemi saat ini melangsungkan penelitian tidak di dalam kelas namun dirumah anak didik. Hal ini dilakukan sesuai dengan arahan Pemerintah, serta menjajaki Protokol Kesehatan di Indoenesia pada saat pandemi untuk mengimbau masyarakat untuk mencari nafkah, melakukan proses pengajaran dan belajar dirumah, serta ibadah dari rumah agar mengupayakan memberlakukan pembatasan berinteraksi ataupun menjaga jarak (social distancing), menghindari kerumunan agar memutuskan rantai penyebaran Coronavirus Disease (Covid- 19). Kementerian Pendidikan dan Kebudayaaan Kemendikbud) pun memberi peringatan kepada para pendidik untuk dapat menjalani pengajaran yang mengasyikkan dari rumah untuk anak didik lewat media online ataupun pembelajaran dalam jaringan( daring) seperti menggunakan Zoom, Whatsapp, Google Meet, ataupun menggunakan website lembaga sekolah. Menurut peneliti, tujuan dari membuat media box of number, and alfabeth sebagai metode menstimulasi agar anak usia dini dapat mengenal abjad, dan angka dengan cara yang berbeda menggunakan box yang unik, dan berwarna. Selain itu dapat mengasah kota kata dalam bahasa anak, menyebutkan angka, huruf-huruf abjad, melatih rasa percaya diri anak dengan menyebutkan huruf maupun abjad di depan kelas, adanya interaksi anak dengan guru agar terciptanya suasana belajar kondusif.

\title{
Tabel 1. Tahapan Kegiatan Mengajarkan Anak menggunakan media Box of Number and Alfabeth
}

\begin{abstract}
No. Proses Aktivitas Mengajarkan Anak Usia Dini dengan memakai Media Box of Number, and Alfabeth
1. Merencanakan untuk tahapan pertama untuk perencanaan agar yang telah dilakukan oleh pendidik kemudian melakukan kegiatan pembelajaran dikelas peneliti terlebih dahulu mempersiapkan media yang berupa box of number, and alfabeth. Periset mempersiapkan media box of number, and alfabeth serta memastikan indikator pencapaian anak (Menyimpulkan kemudian di dengar kosa kata yang lebih, melaksanakan kegiatan yang menampilkan anak sanggup memahami bendadengan mengelompokkan barang di lilngkungannya

2. Pelaksanaan, pada tahap ini pendidik meminta anak untuk duduk membentuk lingkaran, kemudian pendidik menampilkan media box of nurmber and alfabeth dan menjelaskan materi yang hendak ia disampaikan. Salah satu anak mengambil kepingan huruf, dan abjad kemudian memasukan ke dalam box yang telah berisi tulisan angka ataupun abjad agar menyesuaikan memasukkan ke dalam tempatnya masing- masing

3. Penilaian, bersumber pada hasil observasi yang dilakukan di RA Miftahul Huda dalam kegiatan belajarmengajar yang sudah dilakukan pada saat melakukan observasi langsung.
\end{abstract}
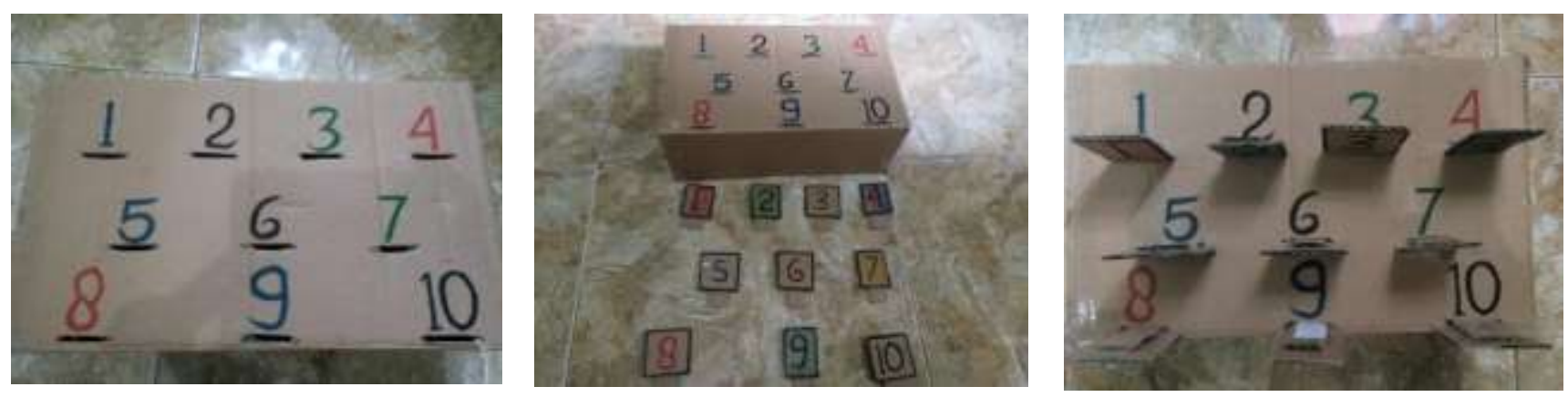

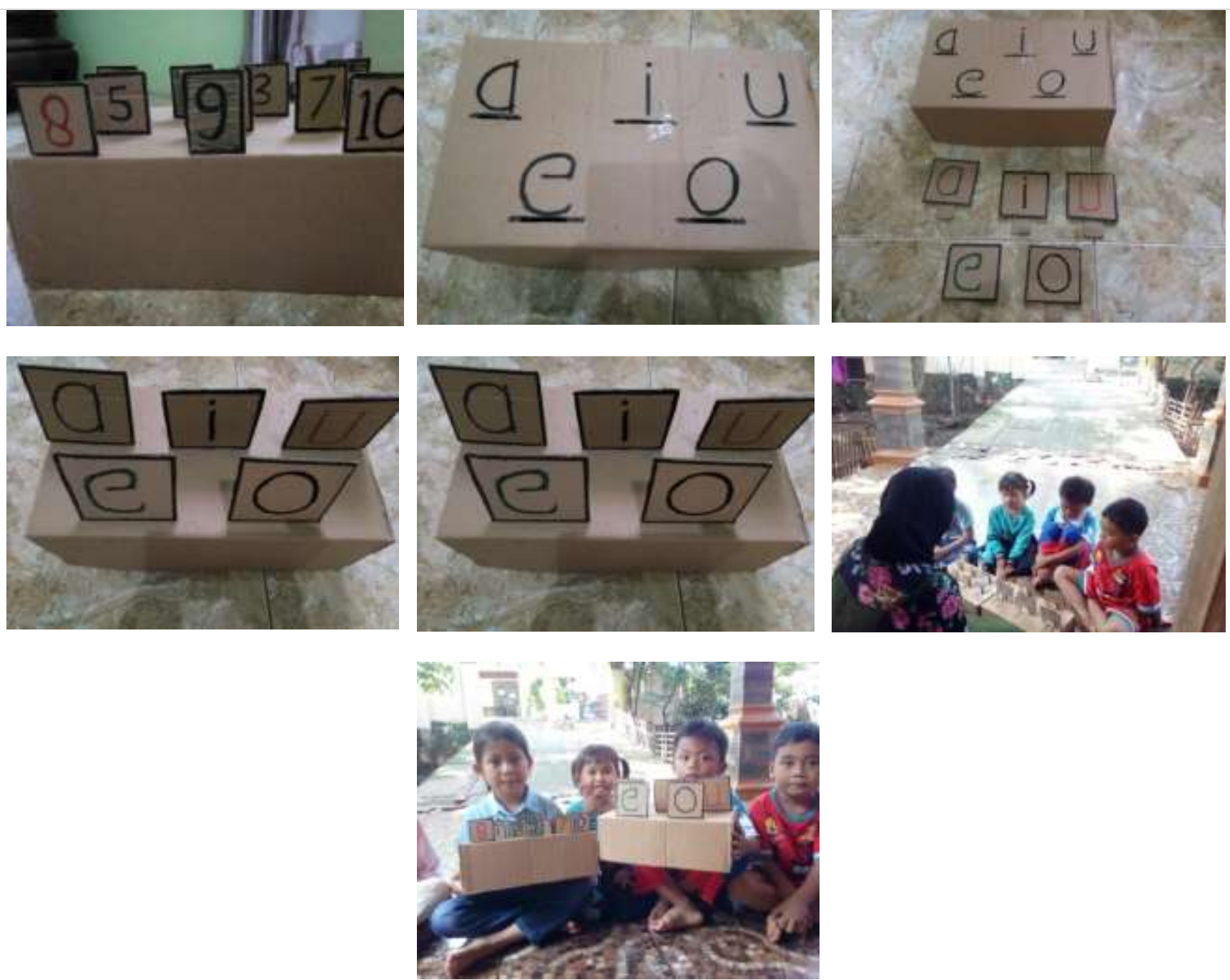

\section{Gambar Anak kelas A dan B mencoba media Box of Number and Alfabeth}

Bersumber pada hasil riset yang dilakukan bertempat di RA Miftahul Huda Cirebon yang dterapkan pada kelas A, dan kelas B menampilkan jika ada kemajuan signifikan kemampuan kognitif, dan kemampua bahasa anak dengan memakai media box of number, and alfabeth. Dengan adanya media box of number, and alfabeth sangat membantu anak kelas A, dan B dalam merangsang kemampuan kognitif anak, anak menggunakan media tersebut dapat melatih kemampuan berpikir anak dengan cara menyebutkan angka maupun huruf yang sudah disediakan peneliti yakni media box of number, and alfabeth. Pada saat anak sulit menyebutkan angka ataupun huruf dapat dibantu dengan media agar dapat memudahkan anak untuk menyebutkan sesuai dan tepat, anak akan merasa nyaman belajar ketika mampu memberikan suasana belajar yang menyenangkan dengan cara belajar sambal bermain. Selain itu, media box of number, and alfabeth dapat melatih kemampuan bahasa menyebutkan angka maupun huruf secara bertahap, dan pengucapan perhuruf maupun perangka secara perlahan sehingga anak akan mengingat kemudian mencontohkan dalam pengucapan, dapat melatih kemampuan bahasa anak sedari dini. Orang tua dengaan pendidik mempunyai peran masing-masing dalam memberikan stimulasi kognitif maupun bahasa anak, dan orang tua dapat bekerja sama dengan pendidik serta mengkomunikasikan perkembangan anak agar dapat optimalisasi tumbuh kembang anak.

Media yang unik agar anak tidak bosan dan agar pembelajaran tidak monoton sebab pentingnya sebagai pendidk menghasilkan keadaan belajar yang menyenangkan bagi anak usia dini, berinovasi agar anak- anak tidak monoton saat belajar dikelas. Tidak hanya anak dapat melatih kemampuan kogitif mapun kemampuan bahasa, media box of number, and alfabeth memiliki manfaanya adalah anak memahami angka, serta huruf- hurf abjad dengan metode yang berbeda, serta unik. Inovasi terkini buat anak belajar, serta memahami angka ataupun huruf- huruf abjad melaui media box of number, and alfabeth dengan metode yang mengasyikkan. Dapat melatih anak dalam rasa yakin diri untuk mengungkapkan di depan kelas, berinterkasi dengan guru ataupun sahabat sebayanya seperti belajar sembari bermain yang mengasyikkan untuk anak. Hal ini sependapat dengan penjelasan dari Huizinga yang dilansir Khadijah bahwasanya bermain ialah aksi ataupun banyak aktivitas menyenangkan, berlandaskan peraturan namun menyenangkan untuk anak bertujuan yang terletak pada diri anak, dan merasakan rasa bahagia (Khadijah, 2017). 
Perkembangan yang sangatlah pesat kemajuan dalam kemampuan berbahasa, aspek bahasa terdapat di semua aspek perkembangan anak usia dini. Seperti halnya agar dapat memaparkan komentar, mengucakan yang ingin dilontarkan, dan menuntaskan permasalahan dalam aspek kognitifmaka dari itu kemampuan berbahasa anak sangat diperlukan sekali untuk 6 aspek perkembangan sebab saling berkaitan satu dengan yang lainnya. Perkembangan bahasa dipengaruhi oleh keluarga dikarenakan pendidikan dalam keluarga hal terpenting termasuk kemampuan bahasa anak, dan akan terjadi pencampuran bahasa daerah dengan bahasa indonesia. Sebab akan mempengaruhijika menetap di suatu daerah yang menunakan bahasa daerah, jika menetap di DKI anak akan terbawa bahasa betawi, dan bercampur dengan bahasa Indonesia, logat pun akan terbentuk dengan sendirinya secara natural.

Perkembangan kognitif anak usia dini contohnya seperti: 1) Anak diajarkan menyelesaikan masalah sederhana yang terdapat di keseharian anak-anak; 2) berpikir menggunakan logika termasuk dalam membedakan, mengetahui sebab akibat; dan 3) berpikir simbolik mengenal benda sekitar, mampu megenal huruf maupun abjad, mengabungkan kosa kata. Jika indikator capaian perkembangan anak mengalami kemajuan pesat berkat stimulas dari orang tua yang selalu memberikan rangsangan 6 aspek perkembangan termasuk kognitif, dan bahasa (Selvi, 2020). Sejalan dengan yang dikatakan oleh Rahman, bahwasanya perkerkembagan kognitif butuh aanya campur tangan dari orang tua supaya penyampaian pertumbuhan anak maksimal, lewat stimulasi pekembangan kognif anak, dan pendidk disekolah perlumenstimulasi prkembangan kognitif anak lewat media box of number, and alfabeth.

Menerapkan bermain sembari belajar agar membantu, menguntungkan terhadap pendidik, dan anak didik sebab dalamproses pembelajaran terciptanya suasana belajar yang menyenangkan, mengasyikan. Peningkatan perkembangan kognitif anak melaui media box of number, and alfabeth dengan metode yang menyenangkan untuk anak pada saat didalam kelas, dan penting untuk pendidik menghasilkan bahan ajar berupa media yang baru, dan inovatif. Pendidik dituntut untuk selalu berinovasi, dan kreatif dalam membuat suatu media ataupun bahan ajar untukmenunjang proses pembelajran saat dimulai agar anak tidak merasakan rasa bosan dengan media pembelajaran yang sudah ada. Pendidik juga dituntut menghasilkan media yang berinovasi, membuat media pembelajaran dengan baik, dan selalu memperbahurui media dengan macam- macam maupun bentuk dari media pembelajaran, contonya seperti media box of number, and alfabeth yang di desain sendiri oleh periset.

Pembelajaran yang dilakukan oleh pendidik dengan anak didik dengan menggunakan media box of number, and alfabeth guna memperkenalkan huruf-huruf abjad, dan memperkenalkan angka dengan cara yang berbeda namun tidak meninggalkan tujuan utama dari media box of number, and alfabeth agar mengasah kemampuan kognitif maupun kemampuan bahasa anak usia dini. Ketika mempraktekan media box of number and alfabeth memakai cara menyenangkan, menciptakan suasana yang kondusif, media box of number, and alfabeth yang akan dipelajarinya bersama anak-anak. Sejalan dengan pendapat Glenn Doman (Ilmiah et al., 2018) neuron anak ketika berusia dini bahkan ketika di dalam rahim ibu stimulasi perlu diterapkan pada anak seperti orang tua mengaji didekatkan pada perut ibu yang sedang mengandung, dan membacakan asma-asma Allah. Manfaat dari stimulasi sejak anak dalam kandungan ibu ketika anak lahir ketika anak berumur 2,5 tahun anak mampu menyebutkan kosa kata, aktif sebab sedari di dalam perut ibu sudah distimulasi oleh orang tua.

Pentingnya kemampuan bahasa, dan kognitif untuk anak usia dini selanjutnya pendidik dan orang tua butuh mengunakan cara yang pas untuk menstimulasi bahasa seta kogntif anak. Menggunakn cara yang pas sangat untuk anak untuk merangsang kemampuan anak dalam berlatih berbicara, komunikasi dengan baik, memahami hurufhuruf abjad maupun kata. Menggunakan cara yang pas untuk digunakan dalam memilih metode bermain, bermain adalah perihal yang sangat di gemari anak jika anak melakukan kegiatan bermain, tanpa disadari oleh anak telah melakukan kegiatan belajar kemudian mengucapkan angka dan huruf- huruf ajad, meyebutkan dengan pecaya diri disekeliling teman sebaya anak. Jika dalam berkegiatan belajar penyampaian pendidik dipahami murid sehingga memerlukan perlengkapan tambahan agar menarik atensi anak. Permaianan yang akan digunakan dengan cara bermain media box of number, and alfabeth. Permainan dengan mengunakan media box of number, and alfabeth memiliki banyak kelebihan ialah mempunyai media yang unik, kepingankepingan huruf ataupun abjad dbuat dengan ukuran edang tetapi mebuat rasa ingin tahu anak akan timbuil, yang sangat menarik atensi anak, dan terdadat tulisan abjad ataupun huruf.

Manfaat dari media box of number, and alfabeth sebagai berikut: 1) Dapat menambah keaktifan anak didik dalam proses pembelajaran anak; 2) Anak didik menggunakan media box of number, and alfabeth yang terdapat tulisan angka, abjad, dan kepingan-kepigan dari huruf abjad maupun angka; 3) Untuk memudahkan anak didik dalam penjelasan oleh pendidik dengan cara unik, berbeda agar terciptanya anak memahami apa yang sudah pendidik jelaskan; 4) Pendidik menciptakan proses pembelajaran dikelas dengan cara berfokus pada anak didik; 5) Pendidik dan anak didk mempersiapkan feed back atau yang di kita kenal memberi dan diberi dalam pertanyaan dan jawaban serta tanggapan anak; 6) Pendidik perlu melakukan pembahuruan untuk proses pembelajaran, menciptakan sesuatu yang baru, dan pendidik dituntut selalu memunculkan ide-ide baru; 7) Media dapat digunakan dikelas A maupun B, untuk mengenalkan ataupun mengulang agar tak lupa dan bentuk media yang membuat anak antusias; 8) Ukuran media yang ukuran tepat untuk usia dini jika dibawa; 9) Mendesain bentuk, ukuran, pemilihan warna, dan pemilihan alat bahan bahan ajar yang bernamakan media box of number, and alfabeth ini mempunyai daya tarik sendiri dari 
warna maupun tulisan huruf-huruf abjad maupun kepingan dari huruf abjad, dan angka yang ada pada media box of number, and alfabeth.

\section{SIMPULAN}

Sebagian besar kemampuan kognitif, dan bahasa pada anak dalam tahapan mulai tumbuh dan sesuai dengan indikator pencapaia. Pemilihan sebuah metode dalam pembelajaran oleh seorang pendidik yang melaksanakan pembaharuan inovatif dalam pembuatan media ialah hal yang sangat berarti dalam tahapan aktivitas belajar mengajar di sekolah. Agar mengoptimalkan tahapan belajar-mengajar maka pendidik wajib pandai, kreatif, berinovasi, dan melakukan pembaharuan media pembelajaran, dituntut pula selalu kreatif. Untuk memilih metode yang digunakan untuk dapat meningkatkan kognitif ataupun bahasa anak merupakan dengan memakai metode box of numer, and alfabeth. Pembelajaran dilakukan dengan pemakaian metode box of numer, and alfabeth untuk meningkatkan kemampuan kognitif ataupun bahasa untuk mengenalkan angka, dan huruf.

\section{UCAPAN TERIMA KASIH}

Terima kasih penulis sampaikan kepada pembimbing penelitian ini dan semua pihak yang telah berkontribusi sehingga artikel ini dapat dipublikasikan.

\section{DAFTAR PUSTAKA}

Aip Saripudin. (2017). Strategi Pengembangan kecerdasan Naturalis Pada Anak Usia Dini. Awlady: Jurnal Pendidikan Anak, 3(1). https://doi.org/10.24235/awlady.v3i1.1394

Aisyah, A. (2017). Permainan Warna Berpengaruh Terhadap Kreativitas Anak Usia Dini. Jurnal Obsesi : Jurnal Pendidikan Anak Usia Dini, 1(2), 118. https://doi.org/10.31004/obsesi.v1i2.23

Amini, N. (2020). Media Kartu Kata Bergambar Dalam Meningkatkan Kemampuan Kosakata Anak Usia Dini. 09(02), 119-129. https://doi.org/10.26877/paudia.v9i2.6702

Anggraini, D. (2019). Metode Demonstrasi sebagai Peningkatkan Perkembangan Kognitif Anak. 1, 13-24. https://doi.org/10.14421/jga.2019.41-02

Astuti, R., \& Aziz, T. (2019). Integrasi Pengembangan Kreativitas Anak Usia Dini di TK Kanisius Sorowajan Yogyakarta. Jurnal Obsesi: Jurnal Pendidikan Anak Usia Dini, 3(2), 294. https://doi.org/10.31004/obsesi.v3i2.99

Baharuddin, E. N. W. (2013). Teori Belajar Dan Pembelajaran. Ar-Ruzz Media.

Baharun, H., \& Saleha, L. (2021). Pengelolaan APE Berbahan Limbah untuk Meningkatkan Kecerdasan Kognitif Anak. 5(2), 1382-1395. https://doi.org/10.31004/obsesi.v5i2.763

Debeturu, B., \& Wijayaningsih, E. L. (2019). Meningkatkan Kreativitas Anak Usia 5-6 Tahun melalui Media Magic Puffer Ball. Jurnal Obsesi: Jurnal Pendidikan Anak Usia Dini, 3(1), 233. https://doi.org/10.31004/obsesi.v3i1.180

Hasmalena, H., \& Rantina, M. (2017). Impelementasi Cerita Rakyat melalui Mata Kuliah Pendidikan Seni Tari Usia Dini untuk Meningkatkan Kreativitas Pada Mahasiswa PG-PAUD FKIP UNSRI. Jurnal Obsesi : Jurnal Pendidikan Anak Usia Dini, 1(2), 81. https://doi.org/10.31004/obsesi.v1i2.18

Hignasari, L. V. (2020). Analisis Peluang Usaha Pembuatan Alat Permainan Edukatif Anak Selama Masa Pandemi Covid-19. Jurnal Ilmiah Vastuwidya, 3(2), 14-22. https://doi.org/10.47532/jiv.v3i2.209

IImiah, J., Volume, P., Fisik-motorik, P. P., \& Calista, W. (2018). I P a g e 170. 4(2), 170-182.

Islam, P., Usia, A., \& Gresik, U. M. (2021). Jurnal Obsesi : Jurnal Pendidikan Anak Usia Dini Peran Orang Tua dalam Mendukung Kegiatan Pembelajaran di Rumah pada Masa Pandemi Abstrak. 5(1), 549-558. https://doi.org/10.31004/obsesi.v5i1.630

Khadijah. (2017). Bermain Dan Permainan Anak Usia Dini. Perdana Publishing.

Made, N., Suryaningsih, A., \& Rimpiati, N. L. (2018). Jurnal Obsesi : Jurnal Pendidikan Anak Usia Dini Implementation of Game-Based Thematic Science Approach in Developing Early Childhood Cognitive Capabilities. 2(2), 194-201. https://doi.org/10.31004/obsesi.v2i2.90

Mardliyah, S., Yulianingsih, W., Surya, L., \& Putri, R. (2021). Jurnal Obsesi : Jurnal Pendidikan Anak Usia Dini Sekolah Keluarga: Menciptakan Lingkungan Sosial untuk Membangun Empati dan Kreativitas Anak Usia Dini Abstrak. 5(1), 576-590. https://doi.org/10.31004/obsesi.v5i1.665

Mulyani, N. (2017). Penerapan Model Pembelajaram Kooperatif. Ar-Raniry.

Novita, C. C. (2020). Aulad: Journal on Early Childhood Penggunaan Mainan Kartu Kata Membaca Berputar Berbasis Teknologi Untuk Anak Usia Dini. 3(3), 132-138. https://doi.org/10.31004/aulad.v3i3.82

Pane, E. T. T. (2012). PAUD Menyiapkan Masa Depan Anak. Universitas Terbuka.

Prahesti, S. I., Taulany, H., \& Dewi, N. K. (2019). Gerak dan Lagu Neurokinestetik (GELATIK) untuk Menumbuhkan Kreativitas Seni Anak Usia Dini. Jurnal Obsesi: Jurnal Pendidikan Anak Usia Dini, 4(1), 162. https://doi.org/10.31004/obsesi.v4i1.289

Ra, D. I., \& Bima, B. (2021). Implementasi kurikulum 2013 (terpadu) di ra baiturrahman bima cirebon. 6(1), 47-58. 
Sari, H. M., \& Nofriyanti, Y. (2019). Peningkatan Kreativitas Anak Usia Dini melalui Kegiatan Menganyam dengan Origami. Jurnal Obsesi: Jurnal Pendidikan Anak Usia Dini, 4(1), 146. https://doi.org/10.31004/obsesi.v4i1.247

Satrianingrum, A. P., \& Prasetyo, I. (2020). Persepsi Guru Dampak Pandemi Covid-19 terhadap Pelaksanaan Pembelajaran Daring di PAUD. Jurnal Obsesi: Jurnal Pendidikan Anak Usia Dini, 5(1), 633. https://doi.org/10.31004/obsesi.v5i1.574

Selvi, I. D. (2020). Jurnal Obsesi : Jurnal Pendidikan Anak Usia Dini Implementasi Mainan Susun Balok Seimbang Berbasis Kearifan Lokal Yogyakarta untuk Anak Usia Dini Abstrak. 4(1), 373-382. https://doi.org/10.31004/obsesi.v4i1.345

Suyadi, M. U. (2015). Konsep Dasar PAUD. PT Remaja Rosdakarya.

Warna, M., Dan, H., Pada, B., \& Usia, A. (2018). Mengenal warna, angka, huruf dan bentuk pada anak usia dini melalui animasi interaktif. 3(2), 103-110.

Wasik, C. nSeefeldt \& B. A. (2012). Pendidikan Anak Usia Dini. PT Indeks.

Yaswinda, Y., Yulsyofriend, Y., \& Sari, H. M. (2020). Analisis Pengembangan Kognitif dan Emosional Anak Kelompok Bermain Berbasis Kawasan Pesisir Pantai. Jurnal Obsesi : Jurnal Pendidikan Anak Usia Dini, 5(2), 996-1008. https://doi.org/10.31004/obsesi.v5i2.711 